Book Review

\title{
Structural Characteristics of Islamic Penal Law
}

By Hedeaki Homma. Niigata, Japan: International University of Japan, 1986, 104 Pp. (Institute of Middle Eastern Studies, Working Paper Series No. 6).

This book, submitted initially as a master's thesis to the Institute of Middle Eastem Studies and then published as a working paper, consists 
of four chapters and a conclusion. The first three chapters are devoted to discretionary ( $t a ' z \bar{r}$ ) and prescribed (hadd) punishments, as well as those for injury and murder. The last chapter discusses themes in the philosophy of punishment, their relevance to Islamic and western law and, to a lesser degree, provides comparisons with Japanese law. The two main objectives, as stated on the first page, are "to scrutinize the nature of the Islamic penal system and . . . investigate the possibility of applying it to the Islamic countries."

The author advances the theme that, in general, penalties in Islamic law are predicated on defending and safeguarding the interests of the Muslim community (i.e., the ummah Islämiyah, as the author frequently calls it). As the family is its stable foundation, threats to its integrity (i.e., illicit sexual relations [zina $\bar{\prime}]$ and slanderous accusations [qadhf]) are punished severely to protect the community's morality (pp. 34,38 ).

He says further that Islamic penal law has a dual structure. The first level consists of prescribed punishments (hadd), retaliation (qișäs), and blood money (diyah), while the second one is that of discretionary punishments (ta'zir). The main purposes of the former are deterrence and personal retribution, whereas those for the latter are more versatile, as they cover all transgressions and can be applied as additions or alternatives to first-level punishments.

Homma characterizes Islamic penal law by its diversity of punishments, especially in the area of $t a$ zir, which responds best to demands for reform and "fulfills its important function as guardian of Islamic justice from all angles" (p. 80). While imprisonment is the dominant western form of legal punishment, Muslim jurists do not consider it as effective as corporal punishment for an individual's reform (p. 23). But, he adds, all punishment in itself constitutes an evil in Islamic law, a fact that can be seen clearly with regard to the more severe prescribed punishments, which are restricted both in number and in the higher standards of proof required for their subsequent enforcement (p. 81). The author lists six actions for which a specific punishment is prescribed: adultery, false accusation, theft, highway robbery, wine drinking, and apostasy (p. 4). However, he fails to mention variant positions taken by such scholars as Mustafā Ahmad al Zarqā (Al Madkhal al Fiqhī al 'Āmm, vol. I, p. 50) and Yūşuf al Qarađāwī (Sharîat al Islām Sālihah li al Tațbìq fī Kull Zamân wa Makān, p. 122). These two scholars claim that there are only four or five actions (i.e., deleting wine drinking and apostasy from the list) necessitating a prescribed punishment, based on the fact that the Qur'an does not prescribe a particular punishment for these offenses.

As for his second theme, Homma states that the applied penal law of Muslim countries is a compound of Islamic and western systems in which the latter is the more dominant. The introduction of westem law into the Muslim world was considered indispensable for its modemization: "How- 
ever Western law has not reduced the number of criminals or enhanced the standard of living" (p. 2). Western law is largely reflective of European history, religion, and culture and differs widely from Islamic law. Thus it is only natural for Islamic countries to try to establish their own legal system, as it is the one best suited to their culture, history, and Islam, "because the legal system of European countries is not superior to the Islamic one." Having said this, Homma adds, correctly, that the revival of Islamic penal law must be espoused with the revival of independent inquiry and ijtihad, for the legal opinions of thirteenth-century Muslim jurists cannot be applied to modern society. Moreover, Muslim jurists must be independent of "mundane authority," and there must be a concrete and fixed standard for mujtahids as well as a procedure to resolve possible disputes among them (p. 17).

The author places considerable emphasis on the traditional mode of ijtihad by individual jurists. In this context, he discusses the philosophy and purpose (hikmah) of the revealed law in contradistinction to the more technical concept of effective cause ( illah). Hikmah is highly conceptual, and ijtihad formulated on its basis could well be "independent of the strict literal meaning of the revelation." Strict rules may be modified, but the law's basic purpose must be upheld (pp. 90-91). Without mentioning al Shātibī, who is renowned for his more philosophical approach to an understanding of the Shari'ah's objectives (maqāsidid), Homma seems to have adopted essentially the same approach. Such recent works as Khalid Masud's Islamic Legal Philosophy and Ahmad al Raysūn̄̄'s Nazarīyat al Maqāsid 'ind al Imām al Shâtibì offer a fuller treatment of the same general theme. By emphasizing individualized ijtihad, Homma shows that he is unaware of the tendency of Muslim scholars, in recent decades, to move away from individual ijtihad and towards collective ijtihad, which is broadly based and draws upon the combined expertise of Shari'ah specialists as well as those in other disciplines.

Homma asserts that, in Islam, law and religion are so inseparable that "to separate law from religion is to negate Islam . . . there is no borderline between law and morals" (pp. 3, 6, and passim). These categorical statements do not take into account certain aspects of Islamic law that are premised on the very separation of law and religion as well as of morality and law. Note, for example, the moral categories of discouraged (man$d \bar{u} b)$ and hated (makrūh) in contradistinction to the legal categories of obligatory (wäjib) and prohibited (harām), or the generally acknowledged distinction between religious obligations (wäjib dini $i$ ) and juridical obligations (wājib qadā' $i$ ). I have discussed this issue at length in my "An Analysis of Haqq in Islamic Law," AJISS 10, no. 3 (Fall 1993).

I also find Homma's categorical statement that "no one has legislative authority" in Islamic law to be somewhat less than accurate. The doctrines of siyāsah shar 'iyah (a Shari'ah-oriented policy) and istisläh (con- 
sideration of public interest), for instance, entitle the lawful authority (the $u l \bar{u}$ al $a m r$ ) to take all necessary measures, including legislation, to secure the community's benefit or to protect the people against a manifest harm (for further detail, see my article "Siyāsah Shar iyah or the Policies of Islamic Government," AJISS 6, no. 1 [September 1989]).

Although the book is well written and concise, it suffers from weaknesses in documentation and reliance on secondary sources. But even so, Homma's research is premised on sound and reasonable objectives and offers a balanced and impartial treatment of its subject. The author has undoubtedly made a distinctive contribution to the advancement of a perspective and framework for the future of Islamic penal law.

Mohammad H. Kamali College of Laws International Islamic University Selangor, Darul Ehsan, Malaysia 